\title{
Enzymatic degradation and fermentation of Corn Bran for Bioethanol production by Pseudomonas aeruginosa AU4738 and Saccharomyces cerevisiae using Co-culture technique
}

\author{
Michael Bamitale OSHO ${ }^{1 \text {,* }}$ \\ ${ }^{1}$ McPherson University, College of Natural and Applied Sciences, Department of Biological Sciences, , Seriki Sotayo, \\ P.M.B. 2094, Sapon, Abeokuta, Ogun State, NIGERIA
}

\begin{abstract}
Ethanol is one of the bioenergy sources with low environmental and high efficiency impact. The aim of this study was to screen for the bacterial isolate capable of degrading starch, investigate the enzymatic hydrolysis and fermentation of corn bran through submerged fermentation using co-culture technique for bioethanol production. The isolate was identified using 16S rRNA sequence technique as Pseudomonas aeruginosa AU4738. Corn bran was used as substrates with and without garlic powder (Allium sativum L.) as activator and subsequently optimized for production of bioethanol. Reducing sugar from the hydrolysate and ethanol concentration of the distillate were analyzed using spectrophotometry and gas chromatography mass spectrometry techniques respectively. There was an increase in glucose concentration $(23.8 \%$ and $17.8 \%)$ in the culture medium with and without activator at $48 \mathrm{~h}$ respectively but steadily decreased from $72 \mathrm{~h}$ to $168 \mathrm{~h}$. Maximum ethanol concentration obtained in substrate culture with activator was $35 \%$ higher compared with that without activator at $120 \mathrm{~h}$ fermentation time. Thus a cheap, renewable and readily available agricultural waste has been effectively utilized as substrate for bioethanol production and incorporation of activator also had significant effect on the viability of fermenting organisms thus subjugating the intolerance of alcohol concentration.
\end{abstract}

\section{Article info}

History:

Received: 04.12.2020

Accepted: 07.09.2021

Keywords:

Corn bran,

Bioethanol,

Pseudomonas

aeruginosa AU4738,

Saccharomyces

cerevisiae,

Co-culture technique.

\section{Introduction}

Sources of biofuel have become more salient as economical substitute to declining and much exorbitant fossil fuels [1]. Bioethanol is the only liquid fuels that do not contribute to the greenhouse gas effect [2]. Due to fluctuating prices and dwindling oil reserves at global market, fermentation processes have attracted great demand in comparison to conventional production of bioethanol [3]. Thus high cost has resulted to energy catastrophe in african countries that are oil contingent. It has been delineated that in many part of the world biofuel remains censorious energy development target if petroleum prices be a cut above US \$ 60

per barrel [4]. Brazil is the world prime biofuel producer and Nigeria has joined the confederation of biofuel users from sugarcane and cassava sources [5]. Cassava, yam, and sweet potato are main starches that serve as staple foods for people throughout the world's humid and hot regions [6]. However, potatoes are high starchy value crops which do not require complex pretreatment. Waste byproducts from sweet potato cultivation could be utilized for bioethanol production $[7,8]$. The use of these staple starchy crops poses threat to food surveillance in the face of growing ethanol fuel demand. Imaginably, the divergence of food resource to bio-fuel production may to a large extent cause food crises worldwide [9]. As a result it becomes exigent that spotlight be turned to the use of non-food starchy piece for bioethanol production.

Saccharomyces cerevisiae (baker's yeast) is one of the most significant microbes in the fermentation of sugar to bioethanol due to its high tolerance to ethanol concentration, high fermentation rate, high ethanol yield, high selectivity, good tolerance to substrate concentrations, low accumulation of by-products, and lower $\mathrm{pH}$ value $[10,11]$. Several researchers, Abouzied and Reddy, [12], Oyeleke et al., [13] Duhan et al., [1] George et al., [14] combined Saccharomyces cerevisiae with other group of saccharifying fungi such as Aspergillus sp., Kluyveromyces sp., Zymomonas 
mobilis, Gloeophyllum sepiarium, Trichoderma sp. and Pleurotus ostreatus to improve bioethanol production. This research was aimed at assessing the appropriateness of using the corn bran through twostep processes: saccharification and fermentation using co-culture method for bioethanol production by Pseudomonas aeruginosa AU4738 and Saccharomyces cerevisiae. Evaluation of the substrate pre-treatment processes for transformation of starch into fermentable sugar and successive use of the spice from garlic as activator was conducted to alleviate product inhibition potency of microorganism in the production of ethanol.

\section{Materials and Methods}

\subsection{Materials}

The bacterial isolate was obtained from Culture Collection Centre, Department of Biological Sciences, McPherson University, Seriki Sotayo, Nigeria and was characterized using $16 \mathrm{~S}$ rDNA sequencing technique while the baker's yeast was purchased from Apongbo Market, Lagos Island Local Government, Lagos. Corn bran, soya beans and garlic were purchased from Awolowo Market, Sagamu, Remo North Local Government, Ogun State, Nigeria. Nutrient agar (NA) (Accumix, Diagnostic, Ltd., India), Yeast Extract Agar (YEA) (LOBA Chemie Pvt. Ltd. India). Iodine, 3,5Dinitosalicyclic acid (DNS) (Baker Inc., USA), sodium potassium tartrate (Klincent Laboratories, Mumbai, India) and Tetraoxosulphate (VI) acid were of analar grade.

\subsection{Methods}

\section{Screening of starch hydrolyzing bacteria}

Pure culture of the bacterial isolate was inoculated into nutrient agar containing $1 \mathrm{~g}$ soluble starch and stay for $5 \mathrm{~min}$ and visualized for hydrolytic activity. Clear zones which appeared around growing bacteria indicate hydrolysis of starch [15].

\section{Determination of hydrolysis rate of the isolate}

Ability of the bacterial isolates to degrade starch was described by the starch degrading index (SDI). The isolate was re-plated on starch agar and their halo diameter $(\mathrm{Z})$ and colony diameter $(\mathrm{C})$ was determined after $24 \mathrm{~h}$ incubation at $35^{\circ} \mathrm{C}$. The formula $\mathrm{Z}-\mathrm{C} / \mathrm{C} \times$ 100 was employed to calculate the percentage hydrolysis efficiency according to the method of Sreedevi and Reddy [16].

\section{Molecular identification of gene sequences of the bacterial isolate}

The total genomic DNA extraction, Polymerase Chain Reaction (PCR) and DNA sequencing according to the standard protocols were carried out. The isolate which demonstrated starch degrading ability was subjected to extraction of total genomic DNA according to the procedures of Zymo Research Bacterial DNA MiniPrep ${ }^{\mathrm{TM}}$ instruction manual and kit.

In determining the phylogenetic grouping of sample genomic DNA, this was amplified using standard PCR. The genomic DNA extract was amplified using PCR reaction and completed within 36 cycles under conditions of initial denaturation $\left(94{ }^{\circ} \mathrm{C}\right.$ for $\left.5 \mathrm{~min}\right)$; denaturation $\left(94^{\circ} \mathrm{C}\right.$ for $\left.30 \mathrm{~s}\right)$; annealing $\left(56^{\circ} \mathrm{C}\right.$ for 30 s); extension $\left(72^{\circ} \mathrm{C}\right.$ for $\left.45 \mathrm{~s}\right)$; final extension step (72 ${ }^{\circ} \mathrm{C}$ for $7 \mathrm{~min}$ ); and indefinitely final holding at $10{ }^{\circ} \mathrm{C}$. Thus, this protocol helped to amplify the $16 \mathrm{~S}$ rRNA gene of interest.

A $5 \mu 1$ sample of PCR product reaction mixture was analyzed by $1.5 \%$ agarose gel electrophoresis in $1 \mathrm{x}$ Tris Acetic EDTA buffer. It was run at $80 \mathrm{~V}$ and 107 $\mathrm{mA}$ for $45 \mathrm{~min}$. A staining medium ethidium bromide was applied on the gel and visualization of bands under UV illumination was evidence. The 16S rRNA sequences were determined by fluorescently labeled 16s RNA products analysis generated by PCR cocktail mix on a DNA sequencer AB 373a Stretch (short gun). Primers (27F:AGAGTTTGATCMTGGCTCAG and 1525R: AAGGAGGTGWTCCARCCGCA) were used in all sequencing reactions. The $16 \mathrm{~S}$ rRNA sequences obtained were aligned with the non-reductant nucleotide database at Genbank using the BLAST program (http://www.ncbi.nlm.nch.gov). A phylogenetic tree was constructed by the neighbourjoining method using MEGA 7 package [17].

\section{Preparation and pretreatment of substrates}

Corn bran and soya bean were blended into powdery form using the electric grinder (Marlex, Electroline) and stored in an air tight container prior to use. Garlic was peeled, dried at $40^{\circ} \mathrm{C}$, blended and stored in an air tight container for subsequent use [18].

\section{Preparation of inocula}

The bacterial inoculum was prepared in $50 \mathrm{ml}$ broth containing nutrient broth $(0.65 \mathrm{~g})$, corn bran $(1 \mathrm{~g})$ and soya bean $(0.5 \mathrm{~g})$. The medium was adjusted to $\mathrm{pH} 6.5$ solutions autoclaved and cooled at room temperature. It was inoculated with $100 \mu \mathrm{l}$ Pseudomonas aeruginosa AU4738 $\left(2.3 \times 10^{4} \mathrm{cfu}\right)$ and incubated for $24 \mathrm{~h}$ at $35^{\circ} \mathrm{C}$.

Saccharomyces cerevisiae inoculum was prepared in $100 \mathrm{ml}$ yeast extract broth $(0.75 \mathrm{~g})$, adjusted to $\mathrm{pH} 6.5$ autoclaved, cooled at room temperature and inoculated with baker's yeast $(1 \mathrm{~g})$. It was then incubated at 120 $\mathrm{rpm}$ for $24 \mathrm{~h}\left(30^{\circ} \mathrm{C}\right)[19]$. 


\section{Preparation of production medium and substrate treatments}

Pretreatment slurry of substrate was prepared by adding $20 \mathrm{~g}$ corn bran powder and $2 \mathrm{~g}$ soya bean powder to $250 \mathrm{ml}$ distilled water $(\mathrm{w} / \mathrm{v})$ with and without $1 \mathrm{~g}$ garlic as activator respectively [20]. Production media were prepared in duplicate and adjusted to $\mathrm{pH} 6.5$ and thereafter autoclaved at $121{ }^{\circ} \mathrm{C}$ for $30 \mathrm{~min}$. Co-culture technique involved simultaneous addition of both starch hydrolytic and fermentation microorganisms. Optimized protocol with very little modification was adopted [20]. The adjustment includes fermentation conditions such as ethanol production parameters ( $\mathrm{pH}$ 6.5; temperature 37 ${ }^{\circ} \mathrm{C}$; incubation period $\left.72 \mathrm{~h}\right)$. They were inoculated with P. aeruginosa AU4738 (5 ml) and Baker's yeast (12.5 $\mathrm{mL})$ at the same time and incubated at $37^{\circ} \mathrm{C}$ for $144 \mathrm{~h}$. All the treatments were manually mixed at $24 \mathrm{~h}$ interval to promote uniform utilization of substrate. $\mathrm{pH}$ was checked and also recorded each day.

\section{Generation of glucose standard curve}

Standard glucose stock solution was prepared by dissolving $0.25 \mathrm{~g}$ glucose in $100 \mathrm{~mL}$ distilled water. Working standard solution was also prepared by adding up $10 \mathrm{ml}$ stock solution to the $100 \mathrm{~mL}$.

Glucose standard solution ranging from $0.1-1.0$ $\mu \mathrm{mol} / \mathrm{mL}$ was transferred into clean, dry test tubes, 1 $\mathrm{mL}$ DNS reagent was added to each tube and cotton plugged. A blank was prepared with $1 \mathrm{~mL}$ DNS added, the test tubes were boiled in water bath for $5 \mathrm{~min}$ cooled at room temperature and $9 \mathrm{~mL}$ distilled water was added. Absorbance at $540 \mathrm{~nm}$ using a spectrophotometer (GS-UV11, General Scientific) was read against the blank.

\section{Determination of reducing sugar from the fermented broth}

Fermented broth $(10 \mathrm{~mL})$ was centrifuge at $3000 \mathrm{rpm}$ for $15 \mathrm{~min}$ to obtain supernatant for each sample with duplicates. One (1) $\mathrm{mL}$ supernatant was dispensed into a test tube, followed by another $1 \mathrm{ml}$ prepared DNS reagent. The resulting mixture was boiled at $100{ }^{\circ} \mathrm{C}$ for $5 \mathrm{~min}$, cooled and $10 \mathrm{~mL}$ distilled water was added and absorbance reading was taken at $540 \mathrm{~nm}$. Thus, concentration values were interpolated from the glucose standard curve [18].

\section{Distillation process}

Distillation was carried out using distillation apparatus after fermentation process. Top fermented broth (15 $\mathrm{mL}$ ) was transferred into round-bottom flask with an enclosed distillation apparatus of a running tap water flask in a heating mantle and fixed to the other end of distillation column for the collection of distillate at 78 ${ }^{\circ} \mathrm{C}$ (standard temperature for ethanol production).

\section{Determination of Ethanol concentration}

The ethanol concentration was determined by spectrophotometric method [22]. Distillate $(0.5 \mathrm{~mL})$ was measured into a conical flask containing $15 \mathrm{~mL}$ distilled water, and $12.5 \mathrm{~mL} \mathrm{~K} \mathrm{KrO}_{7}$ solution was added. The resulting mixture $(20 \mathrm{~mL})$ was transferred into a test tube and incubated at $60{ }^{\circ} \mathrm{C}$ for $20 \mathrm{~min}$ in a water bath and then cooled at room temperature. Five (5) $\mathrm{mL}$ was taken and diluted with $5 \mathrm{~mL}$ distilled water and absorbance was determined at $600 \mathrm{~nm}$ using spectrophotometer. The ethanol concentration was calculated from absolute ethanol standard curve, while the ethanol yield was determined using Yoswathana and Phuriphipat [23] procedure as shown below:

$$
\text { Ethanol Yield }=\frac{\text { Ethanol measure in Sample }}{\text { Amount of initial sugar content x } 0.5}
$$

\section{Gas chromatography mass spectrometry (gcms) analysis of bioethanol}

Gas Chromatography Mass Spectrometer (Shimadzu QP 2010 Ultra, Japan) equipped with Mass Spectrometer Detection 5975C (VLMSD) and injector (Auto) 7683B series) was used for the analysis. Absolute ethanol GC grade was used as internal standard in Gas Chromatography measurements. An aliquot $(1 \mu 1)$ reaction medium was measured and diluted in absolute ethanol (GC grade). The column temperature was kept at $40{ }^{\circ} \mathrm{C}$, held for $1 \mathrm{~min}$, raised to $290{ }^{\circ} \mathrm{C}$ at the rate of $3{ }^{\circ} \mathrm{C} / \mathrm{min}$, and then maintained at this temperature for $1.65 \mathrm{~min}$. The final run time was $54.2 \mathrm{~min}$. The detector and injector temperatures were set at 240 and $230{ }^{\circ} \mathrm{C}$ respectively. GC measurements were taken in triplicate.

\section{Results and Discussion}

\section{Screening of microorganisms capable of hydrolyzing starch and hydrolysis efficiency}

Screening of bacterial isolates for ability to hydrolyze starch depends on clear zone exhibition around their colonies. Zone of inhibition obtained from the screened bacterium showed appreciable differences in ability to hydrolyze starch (Figure 1). Hennessy et al. [24] described series of methods for the isolation, screening, and selection of glycoalkaloids (GA)degrading bacteria. The screening of bacterial crude extracts for the ability to hydrolyze GAs was performed using a combination of thin layer chromatography (TLC), high performance liquid 
chromatography (HPLC), and liquid chromatography mass spectrometry (LC-MS). These revealed the principal monomer of sugar constituents available for microorganisms' consumption for hydrolysis.

However, the bacterium in question was selected based on exhibition of halo zone diameter $(19 \mathrm{~mm})$ with calculated hydrolysis efficiency of $63.3 \%$. Occurrence of isolate producing such large diameter of zone of inhibition was an indication that this substrate could serves as potential amylase producing bacterial medium $[16,20]$. The starch hydrolysis was otherwise described by Gudeta (25) as starch degrading index (SDI).

Though the procedures carried out by the extracellularly secreted commercial $\alpha$-amylase from bacteria could be very expensive for large scale production. The zone of inhibition exhibited by the bacterial isolate was an indication that it is more efficient on starch hydrolysis for monomeric sugars production. Furthermore, starch molecules are too large to enter bacterial cells, hence their transportation after hydrolysis into the cell and are thereafter used for metabolism reactions. These exoenzymes vis $\alpha$ amylase and oligo-1,6-glucosidase are able to hydrolyze starch (amylase test) into dextrin, maltose, or glucose subunits using the starch agar as differential nutritive medium [26].

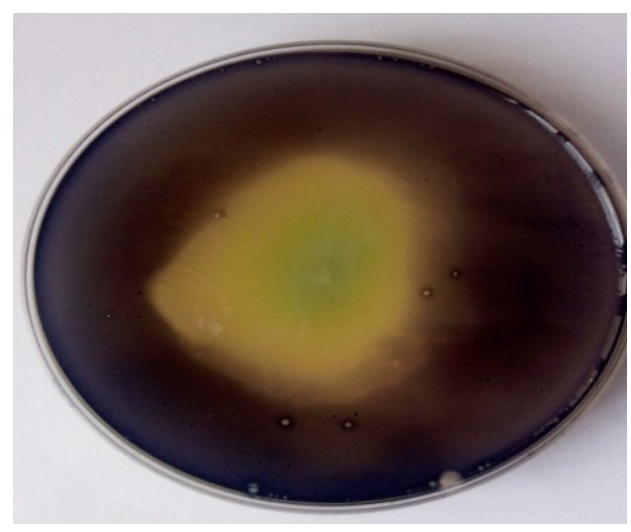

Figure 1. Pseudomonas aeruginosa showing Zone of Clearance on Starch Agar plate

\section{Identification of the PCR amplified 16S rRNA}

The isolate with NCBI Accession number HQ1481651.1 was identified as Pseudomonas aeruginosa AU4738. The maximum percentage identity was $93 \%$ as shown in Figure 2.

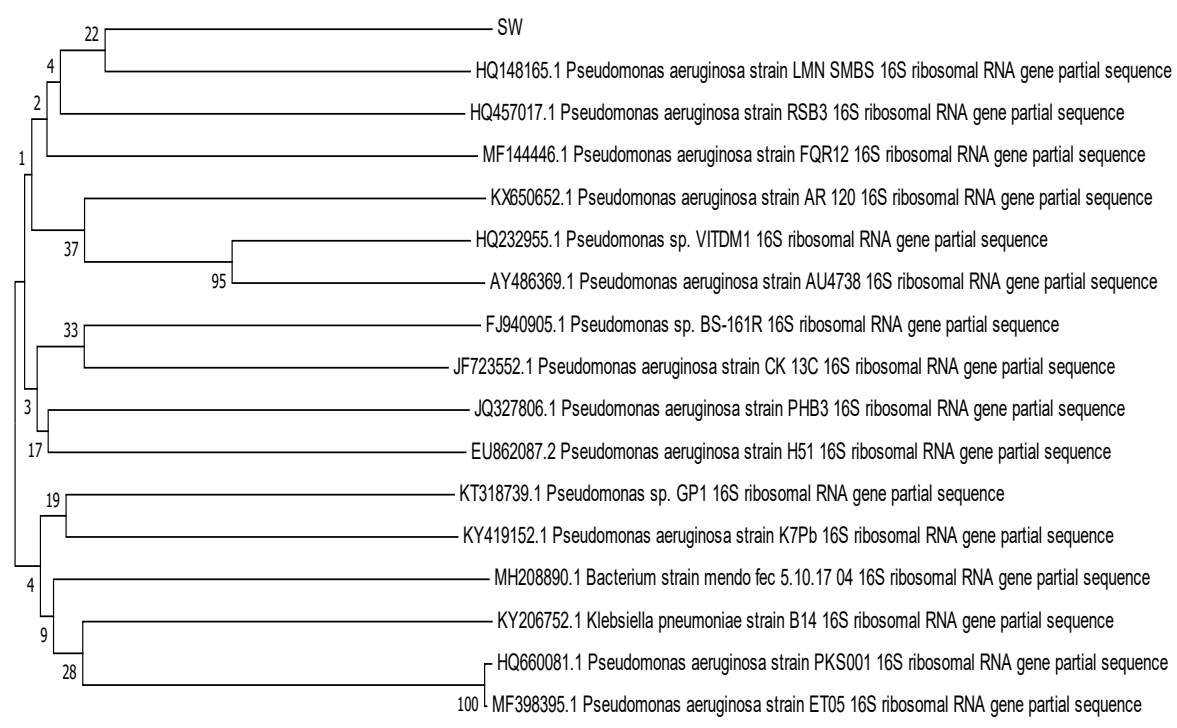

Figure 2. Phylogenetic Tree based on relationship of Pseudomonas aeruginosa strain AU4738

Optimization of the Glucose and Bio-Ethanol from the Corn bran substrate

There was an increase in activity of the starch degrading enzyme for glucose production by 23.8 and $17.8 \%$ at $48 \mathrm{~h}$ in culture with and without activator respectively and a steady decrease at $72 \mathrm{~h}$ to $168 \mathrm{~h}$ (Figure 3). This revealed fast starch-degrading enzyme produced by $P$. aeruginosa AU4738. According to
Zakpa et al., [27] the reducing sugar concentration retention may be directly proportional to the initial starch concentration available in corn bran. Incomplete hydrolysis of starch at a given saccharification time possibly resulted in reduction of reducing sugar that could have been converted even after addition of baker's yeast. This was in conformity with the results of Bekele et al. [28] when they produced bioethanol from potato waste peels. 


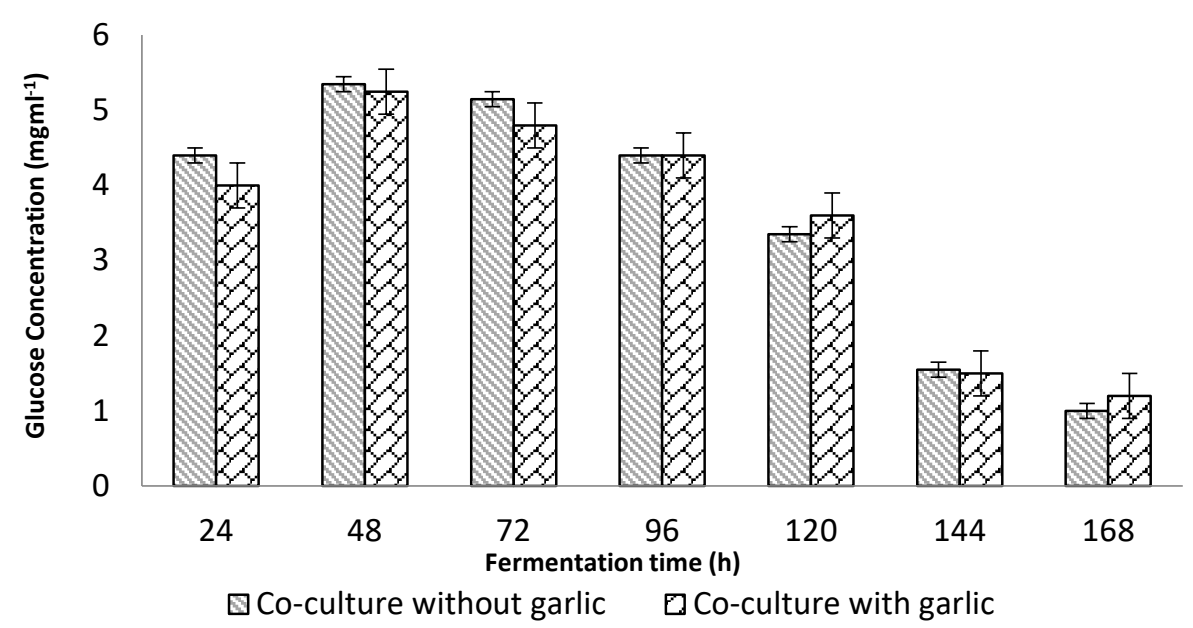

Figure 3. Effect of Culture Techniques on Glucose Production during the Fermentation of Corn Bran with or without Activator

In studying the effect of garlic powder on bioethanol synthesis, activated corn bran has maximum ethanol concentration of $18.25 \% \mathrm{v} / \mathrm{v}$ which was $35 \%$ higher than its counterpart without activator that recorded $11.86 \% \mathrm{v} / \mathrm{v}$ at $120 \mathrm{~h}$ fermentation time (Figure 4). Subsequent fermentation process time drastically reduced the concentration. The procedure could be assumed as an alternative cost-efficiency in the trailing of fuel ethanol production protocol. Moreover, the incorporation of activator in the medium had significant effect on the bioethanol yield. Consequently the intolerance alcohol concentration posed to the viability of fermenting microorganisms was subdued.

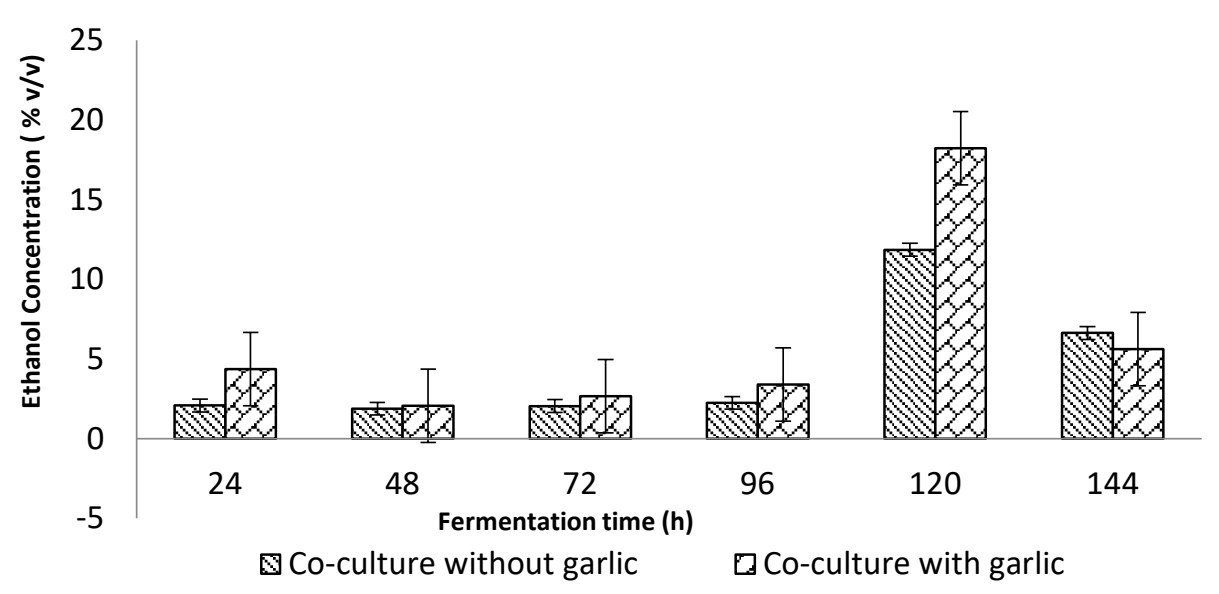

Figure 4. Effect of Culture Technique on Ethanol Production during the Fermentation of Corn bran with or without Activator

Garlic extract has been reportedly used to prevent acetaldehyde synthesis from ethanol by inhibiting the alcohol dehydrogenase [29]. Teixeira et al. [30] noted that the discrimination of alcohol concentration greater than $10 \%(\mathrm{v} / \mathrm{v})$ will pose difficulty on the adequacy of fermenting microbes if it has potential to produce ethanol concentrations $\geq 17 \%$ (v/v). There was a report on reduction in the levels of acetaldehyde and acetate, after the introduction of garlic to investigation animals with significant increase in ethanol concentration [31]. In a work conducted by Abouzied and Reddy, [12] when Aspergillus niger and Saccharomyces cerevisae were co-cultured for bioethanol production, the barrier of the intolerance of the yeast to alcohol concentration was supposedly a concern. The activator circumvented this obstacle which also might be due to its phenolic 
constituent. Garlic has been contemplated as one of the richest vegetable origin for total phenolic compounds [32]. As a result, most researchers now look plant origin for phytochemicals that could specifically target and prevent enzyme synthesize of these fermentation inhibitors distinctively acetate.

Pseudomonas aerugenosa AU4738 and baker's yeast concomitantly employed in this study enhanced the bioethanol synthesis. This was also in agreement with Igbokwe et al., [33] that reported a keen increase in the percentage ethanol yield from 120 to $216 \mathrm{~h}$ incubation. Moreover, from glucose and lignocellulosic biomass hydrolysate substrates according to Joshi et al. [34], ethanol was efficiently and effectively produced by a coalescence of $S$. cerevisiae CDBT2 and $W$. anomalous CDBT7 yeast strains and indicated almost complete utilization of reducing sugars. Contrariwise, there was no improvement in ethanol production obtained after inoculation with $S$. stipitis in the sequential co-culture of $S$. cerevisiae and $S$. stipitis but lower ethanol was recovered with simultaneous coculture in the consumption of xylose and glucose substrates. Moreover, S. cerevisiae fermentation of Kraft pulp hydrolysate in fermenter resulted in a slightly lower ethanol productivity and yield [35].

It has been told of that final ethanol concentration acquired differ either in the type of substrate concentration, pre-treatment given to substrate, mode of operation, substrate detoxification procedure, temperature, or fermentation strain [36]. Consequently ethanol from amylolytic fungus hydrolysates was lower than ethanol from acid hydrolysate of various substrates [37].

\section{Identification test for Bio-Ethanol}

A conventional method for determination of reducing sugars and total alcohols in raw fermentation broths has been developed and widely employed. The fermented broth culture is often pretreated to remove polysaccharides, proteins, glycerol and organic acids. The colorimetric change from total alcohols and reducing sugars were measured by potassium permanganate oxidation and determined by DNS test and subtracted. The remaining portion of colorimetric change was then used to calculate the total alcohol concentration in the sample. However, ethanol concentration can also be determined using ethanol oxidase or ethanol dehydrogenase, but the results are easily disturbed by the presence of various enzymes in the fermentation broth [38]. In this study, the GC analysis revealed $5.73 \% \mathrm{w} / \mathrm{v}$ and $3.6 \% \mathrm{w} / \mathrm{v}$ total component of ethanol from corn bran with and without activator using co-culture respectively as presented in Figures 5 and 6 respectively. However, the ethanol concentration determination by spectrophotometric method was estimated by percentage whereas the GC analysis revealed the component base on proportion, hence the disparity in quantification. Though there are some disadvantages in using this method. Potassium permanganate being unstable as it react with water at low $\mathrm{pH}$ and complicate the test results. To mitigate this setback, potassium permanganate solution was prepared right before it is used and kept in dark.

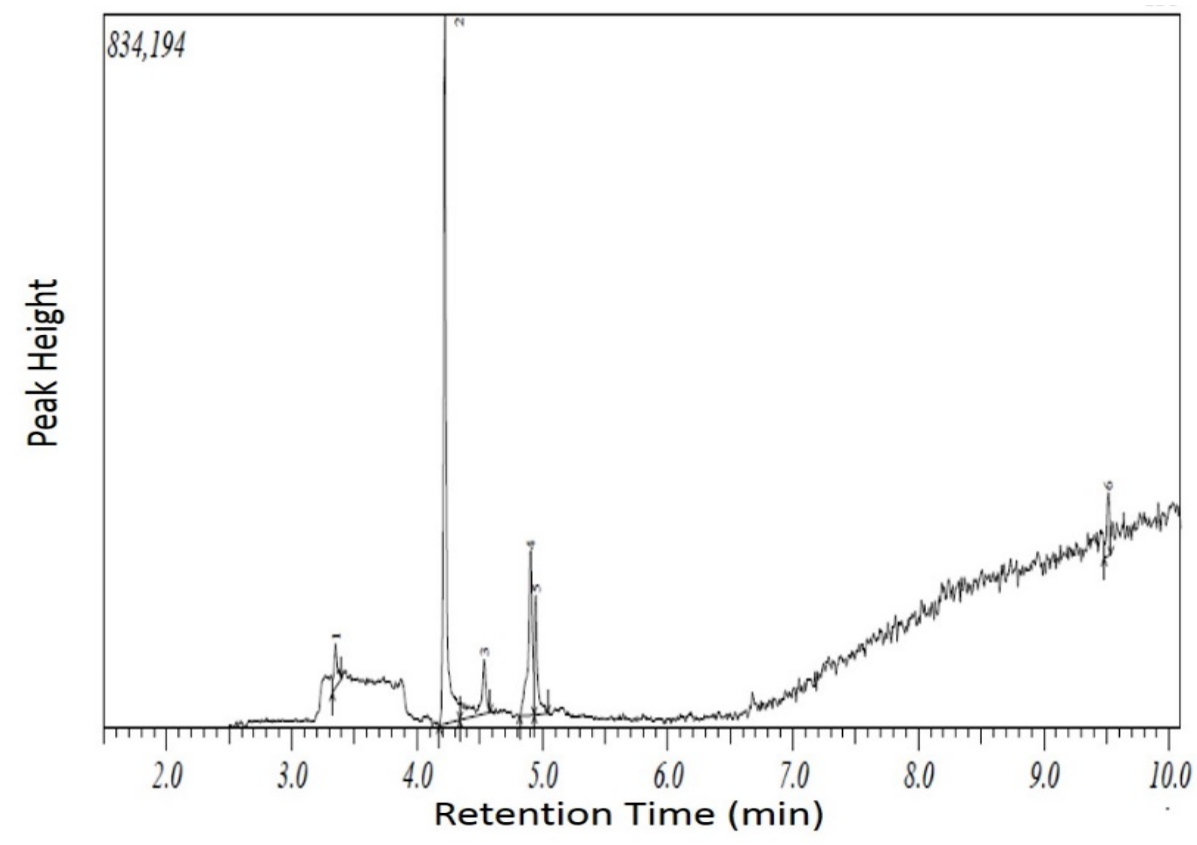

Figure 5. Gas Chromatogram of Ethanol concentration from Corn bran with activator 


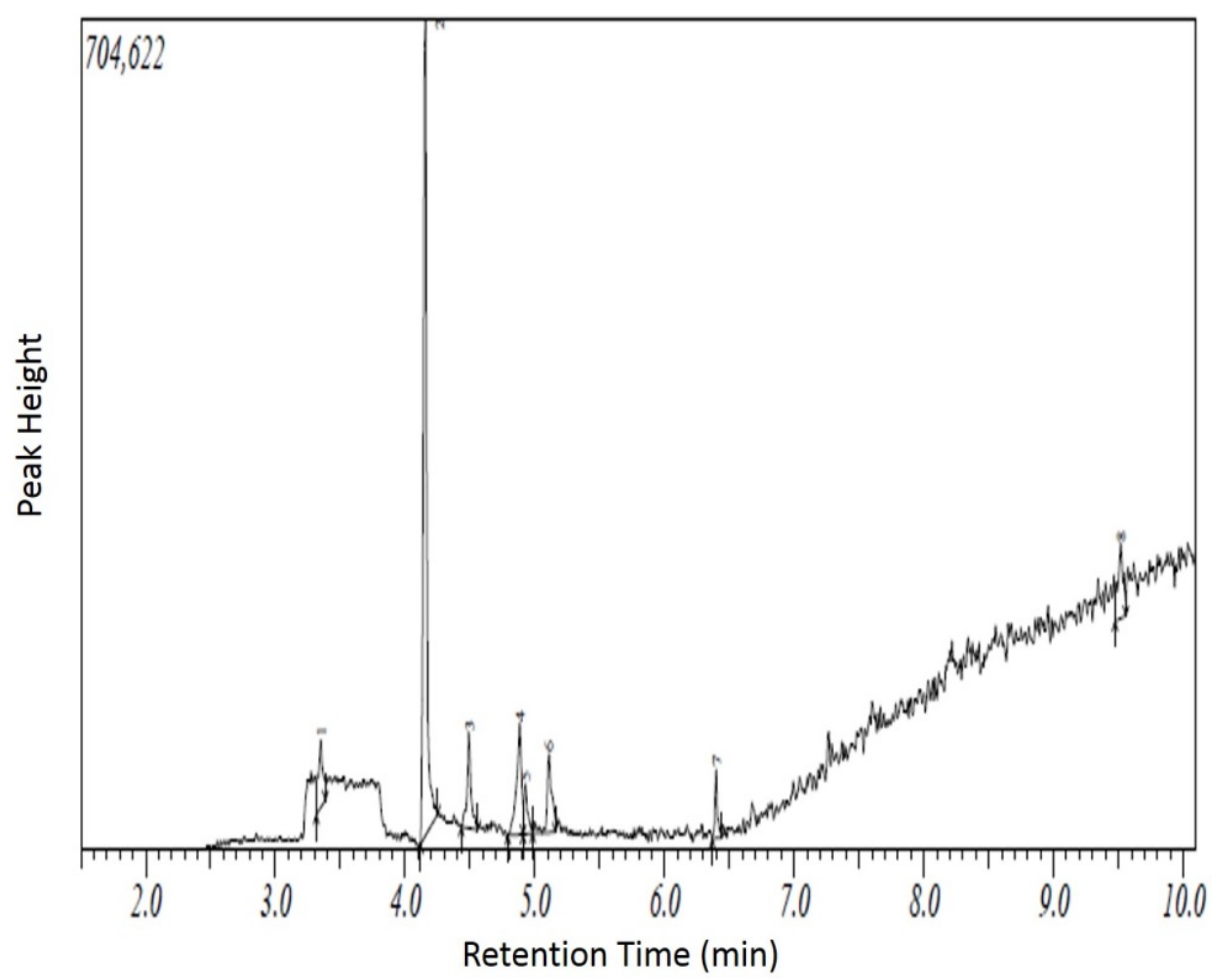

Figure 6. Gas Chromatogram of Ethanol Concentration from Corn Bran without Activator

\section{Acknowledgment}

I would like to acknowledge the Messrs. David Adesida and Kola Kusimo, Laboratory Staff of the Department of Biological Sciences for their technical assistance.

\section{Conflicts of interest}

The author simply declares there is no conflict of interest.

\section{References}

[1] Duhan J.S., Kumar A., Tanwar S.K., Bio-ethanol production from starchy part of tuberous plant (potato) using Saccharomyces cerevisiae MTCC170, African Journal of Microbiology Research, 7(46) (2013) 5253-5260.

[2] Anuj K.C., Ravinder R., Lakshmi M.N., Rao V., Ravindra P., Economic and environmental impact of bio- ethanol production technology, Biotechnology and Molecular Biology Review, 2(1) (2007) 14-32.

[3] Brook A.A., Ethanol potential of local yeast strains isolated from ripe banana peels, African
Journal of Biotechnology, 7(20) (2008) 3749 3752.

[4] Naylor R.L., Liska A., Burke M., Falcon W.P., Gaskell J., Razello S., Cassaman K., The effect: Biofuel, food security and the environment, Environmental Microbiology, 49(9) (2007) 30-43.

[5] Aisien F.A., Aguye M.D., Aisien E.T., Blending of ethanol produced from cassava waste water with gasoline as source of automobile fuel, Electronic Journal of Environment, Agriculture and Food Chemistry, 9(5) (2010) 946-950.

[6] Klass D.L., Biomass for renewable energy fuels and chemicals, London: Academic Press, (1998) 544.

[7] Limatainen H., Kuokkanen T., Kaariainen J., Development of bio-ethanol production from waste potatoes. In: Pongracz, E., (ed.) Proceedings of the Waste Minimization and Resources Use Optimization Conference, Finland, Oulu: Oulu University Press, (2004) 123129.

[8] Adarsha R., Asha D.L. Balaji R.R., Production of bio-ethanol from Pectobacterium carotovorum induced soft rotten potatoes, African Journal of Microbiology Research, 4(12) (2010) 1340-1342. 
[9] Srinorakutara T., Kaewvimol L., Saengow I., Approach of cassava waste water pre-treatment for fuel ethanol production in Thailand, Journal of Science Research, 31(1) (2008) 77-84.

[10] Muhamud F. Bin I., Production of Bio-ethanol from Tapioca Starch using Saccharomyces cerevisiae, PD thesis, University of Malaysia Pahang, (2009).

[11] Lee W., Jin Y., Evaluation of ethanol production activity by engineered Saccharomyces cerevisiae fermenting cellobiose through the phosphorolytic pathway in simultaneous saccharification and fermentation of cellulose, Journal of Microbiology and Biotechnology, 27(9) (2017) 1649-1656.

[12] Abouzied M.M., Reddy C.A., Direct fermentation of potato starch to ethanol by co-culture of Aspergillus niger and Saccharomyces cerevisiae, Applied and Environmental Microbiology, 52(5) (1986) 1055-1059.

[13] Oyeleke S.B., Dauda B., Oyewole O.A., Okoliegbe I.N., Ojebode T., Production of Bioethanol from cassava and sweet potato peels, Advances in Environmental Biology, 6(1) (2012) 241-245.

[14] George P., Aggelos G., Aikaterini K., Styliani K., Dimitris K., Diomi M., Bioethanol Production from Food Waste Applying the Multienzyme System Produced On-Site by Fusarium oxysporum F3 and Mixed Microbial Cultures, Fermentation, 6 (2020) 39.

[15] Farias D.F., Carvalho A.F.U., Oliveira C.C., Sousa N.M., Rocha-Bezerrra L.C.B., Ferreira P.M.P., Hissa D.C., Alternative method for quantification of alpha-amylase activity, Brazilians Journal of Biology, 70(2) (2010) 405407.

[16] Sreedevi S., Reddy B.B.N., Isolation, screening and optimization of phytase production from newly isolated Bacillus sp. C43, International Journal of Pharmacy and Biological Science, 2(2) (2012) 218-231.

[17] Kumar S., Stecher G., Tamura K., MEGA7: Molecular Evolutionary Genetics Analysis Version 7.0 for Bigger Datasets, Molecular Biology Evolution, 33(7) (2016) 1870-1874.

[18] Amadi P.U., Ifeanacho M.O., Impact of changes in fermentation time, volume of yeast, and mass of plantain pseudo-stem substrate on the simultaneous saccharification and fermentation potentials of African land snail digestive juice and yeast, Journal of Genetic Engineering and Biotechnology, 14(2) (2016) 289-297.

[19] Akponah E., Akpomie O.O., Analysis of the suitability of yam, potato and cassava root peels for bioethanol production using Saccharomyces cerevisae, International Research Journal of Microbiology, 2(10) (2011) 393-398.

[20] Swain M.R., Mishra J., Thatoi H., Bio-ethanol Production from Sweet Potato (Ipomoea batatas L.) Flour using Co-Culture of Trichoderma $s p$. and Saccharomyces cerevisiae in Solid-State Fermentation, Brazil Archive of Biology Technology, 56 (2) (2013) 171-179.

[21] Amadi B.A., Agomuo E.N., Ibegbulan CO. Research Methods in Biochemistry, OwerriNigeria: Supreme Publishers, (2004); 93-99.

[22] Caputi A,. Ueda M., Brown T., American Journal of Enology and Viticulture, 19 (1968) 160-165.

[23] Yoswathana N., Phuriphipat P., Bioethanol Production from Rice Straw, Energy Research Journal, 11 (2010) 26-31.

[24] Hennessy R.C., Jørgensen N.O.G., Scavenius C., Enghild J.J., Greve-Poulsen M., Sørensen O.B., Stougaard P.A., Screening Method for the Isolation of Bacteria Capable of Degrading Toxic Steroidal Glycoalkaloids Present in Potato, Frontier Microbiology, 9 (2018) 2648.

[25] Gudeta D., Isolation and characterization of starch degrading rhizobacteria from soil of Jimma University Main Campus, Ethiopia, African Journal of Microbiology Research, 12(32) (2018) 788-795.

[26] Rijal N., Starch Hydrolysis Test: Principle, Procedure, Results. In Mucormycosis: Pathogenesis, Clinical Manifestations and Treatment. Available at: https://microbeonline.com/starch-hydrolysistest/. Retrieved September, 2021.

[27] Zakpa H.D., Mak-Mensah E.E., Johnson F.S., Production of ethanol from corncobs using Aspergillus niger and Saccharomyces cerevisiae in simultaneous saccharification and fermentation, African Journal of Biotechnology, 8(13) (2009) 3018-3022.

[28] Bekele A., Fite A., Alemu S., Sewhunegn T., Bogele E., Simachew M., Debele T., Production of bio-ethanol from waste potato peel collected from University of Gondar, student's cafeteria, Global Journal of Biochemistry and Biotechnology, 3(3) (2015) 132-140. 
[29] Rabinkov A., Miron T., Konstantinovski L., Wilchek M., Mirelman D., Weiner L., The mode of action of allicin: trapping of radicals and interaction with thiol containing proteins, Biochemical and Biophysical Acta., 1379 (1998) 233-244.

[30] Teixeira M.C., Godinho C.P., Cabrito T.R., Mira N.P., Sa'Correia I., Increased expression of the yeast multidrug resistance ABC transporter Pdr 18 leads to increased ethanol tolerance and ethanol production in high gravity alcoholic fermentation, Microbial Cell Facts, 11(1) (2012) 98.

[31] Kishimoto J., Ehama R., Wu L., Jiang S., Jiang N., Burgeson R.E., Re-Selective activation of versican promoter by epithelial-mesenchymal interactions during hair follicle development, Proceedings of National Academy of Science (USA), 96 (1999) 7336-7341.

[32] Martins N., Petropoulos S., Ferreira C.F.R., Chemical composition and bioactive compounds of garlic (Allium sativum L.) as affected by preand post-harvest conditions: A review, Food Chemistry, 211 (2016) 41-50.

[33] Igbokwe P.K., Idogwu C.N., Nwabanne J.T., Enzymatic Hydrolysis and Fermentation of Plantain Peels: Optimization and Kinetic Studies, Advances in Chemical Engineering and Science, 6 (2016) 216-235.

[34] Joshi J., Dhungana P., Prajapati B., Maharjan R., Poudyal P., Yadav M., Mainali M., Yadav A.P., Bhattarai T., Sreerama L., Enhancement of Ethanol Production in Electrochemical Cell by Saccharomyces cerevisiae (CDBT2) and Wicker hamomycesanomalus (CDBT7), Frontier Energy Research, 7 (2019) 70.

[35] Rita H.R.B., Mariana S.T.A., Luísa S.S., Ana MRBX. Ethanol Production from Hydrolyzed Kraft Pulp by Mono- and Co-Cultures of Yeasts: The Challenge of C6 and C5 Sugars Consumption, Energies, 13(3) (2020) 744.

[36] Olofssen K., Bertilsson M., Liden G., A short review on SSF - an interesting process option for ethanol production from lignocellulose feedstocks, Biotechnology for Biofuels, 1(7) (2008) 1-14.

[37] Arotupin D.J., Evaluation of microorganisms from cassava waste for production of amylase and cellulase, Resource Journal of Microbiology, 2(5) (2007) 475-480.

[38] Zhang P., Hai H., Sun D., Yuan W., Liu W., Ding R., Teng M., Ma L., Tian J., Chen C., A high throughput method for total alcohol determination in fermentation broths, BMC Biotechnology, 19 (2019) 30 . 